\title{
Involvement of NGOs in Training Teachers in Education for Sustainable Development in Vietnam: A Case Study
}

\author{
Thi Kinh $\mathrm{Kieu}^{1 *}$, Jane Singer ${ }^{1}$
}

\begin{abstract}
Non-governmental organizations (NGOs) with participatory and experiential approaches have made significant contribution to education for sustainable development (ESD) globally. Examination of five NGO training courses conducted at a Vietnamese teacher education institution reveals that NGOs apply interactive teaching pedagogies that promote student teachers' sustainability competencies, including systems thinking, future thinking, values thinking and an action-orientation. Students in focus groups saw NGOs as crucial educators in non-formal ESD, contributing to promoting ESD at TEIs by helping to raise funds and to provide research funding, offering the promise of future employment, and reviewing curriculum. Yet weak collaboration between NGOs and universities is among the main challenges to NGO involvement in training student teachers in ESD. Thus some initial steps have been proposed to enhance university-NGO partnerships for further collaboration on teaching ESD.
\end{abstract}

Key words: Education for sustainable development, NGOs, teacher education, sustainability competencies

\section{Introduction}

Non-governmental organizations (NGOs) are leading agencies in ESD advancement. They not only work with communities in development projects but also empower youth leaders in environment and sustainability. Therefore, NGOs sometimes involve university students in their activities to promote youth enthusiasm and creativity in sustainability. Particularly, in developing countries, NGOs can help compensate for limited finances and capacity at HEIs by offering students courses and training in ESD. NGOs can also cooperate with university educators to develop curricula and increase community outreach, and they offer potential employment for university graduates.

In order to investigate the contribution of NGOs in bolstering knowledge among youths of education for sustainable development (ESD), this paper presents a case study of NGO involvement in training teachers in ESD at a Vietnamese teacher education institution, Danang University of Education (DUEd). The paper will first examine how NGOs have been involved in training teacher on ESD at DUEd and identify the challenges facing NGOs during their training. Then it will seek to identify roles played by

\footnotetext{
'Graduate School of Global Environmental Studies, Kyoto University, Japan

*corresponding author

Thi Kinh Kieu is a doctoral student of Graduate School of Global Environmental Studies, Kyoto University, Japan. Her research focuses on education for sustainable development at higher education.

Jane Singer is associate professor in the Environmental Education study area, Graduate School of Global Environmental Studies, Kyoto University, Japan. Her research focusses on sustainable development, particularly migration and displacement and community resilience.

Address: Yoshida Honmachi, Sakyo-ku Kyoto, Japan (Postal code: 606-8501)Tel: +81-75-753-5933
} 
NGOs before suggesting some solutions to stimulate NGO participation in ESD at the tertiary education level.

\subsection{NGO contribution in ESD}

NGOs can be defined as well-structured civil society organizations that not only support development but are also involved in decision-shaping and decision-making (Ulleberg, 2009). NGOs play a very active role in the field of education. Through innovations at the micro level, for instance, working with schools, NGO can make changes in a "bottom-up" process (Ulleberg, 2009). In some cases, those innovations have been mainstreamed in education transformation by influencing government's policies. Moreover residents often regard NGOs as more efficient, less corrupt and closer to the community than the government (Egnbol-Martinussen and EngbergPedersen 2003). Thus, NGOs have been involved in and made significant contributions to the Education for All (EFA) movement, a global commitment to provide quality basic education for all children, youth and adults.

NGOs are now paying particular attention to EE (see Haigh, 2006) and ESD (Hopkins, 2014). In fact, NGOs with participatory and interactive approaches have become important non-formal environmental educators (Mochizuki, 2016). Reviewing a variety of publications indicates that NGOs generated diverse initiatives in knowledge-oriented and/or action-oriented programs. Typical initiatives include the following:

- Creating a data bank including EE booklets, pamphlets and documentary films, environment-related teaching guidebooks and good practices, and creating an information distribution network to provide those resources to residents (IGES, 2004; Turnock, 2004; Yeshodhara, 2005)

- Applying interactive pedagogies during training process such as slide/video show, essay, debates, dialogues, radio for lectures (IGES, 2004; Turnock, 2004; Yeshodhara, 2005) and promoting hands-on or experiential learning by field work, field camps, field-project experience, problem-solving, action and change, and role-playing (Haigh, 2006; IGES, 2004; Jia-nan, 2012; Turnock, 2004; Yeshodhara, 2005);

- Increasing learners' expressive output via poetry, paintings and songs (IGES, 2004);

- Utilizing information and communication technology (ICT) to advance knowledge exchange, discussion and action plan among between students from a developed country (Netherlands) and developing countries (Indonesia and Zimbabwe) towards a sustainable society (IGES, 2004);

- $\quad$ Promoting follow-up activities via establishment of eco-clubs, tree-planting and teacher capacity building (IGES, 2004; Yeshodhara, 2005).

Even within a short period these activities can create a very powerful and influential momentum that affects learners' cognition of environment and sustainability (Haigh, 2006). NGOs widely apply experiential pedagogy, a primary methodology to build sustainability leaders, to involve learners in the training process. In addition, with expertise, experience and information resources, NGOs solve existing shortcomings of formal environmental education, which continues to be characterized by knowledgeoriented approaches that do little to encourage behavioral change. The popular themes of NGO training also replicate the environmental teaching content in the formal education system, comprising such topics as ecosystem and biodiversity conservation, air 
pollution, forest conservation, urban environment, environmental awareness programs, nature conservation, pollution control and sustainable development.

Nevertheless, there are several constraints that impede NGO training programs. According to a review of the status of EE in 36 Asian countries (Bhandari and Abe, 2001) and in-depth analysis of NGOs in Indonesia (Nomura and Abe, 2001) (cited in IGES 2004), there are four main limitations of NGO activities: (i) lack of capacity, including lack of organizational management skills, lack of EE skills/knowledge, lack of human resources, and inadequate funding and dependence on funding agencies; (ii) insufficient information-dissemination system; (iii) unfavorable political conditions, and (iv) problems related to a nation's stage of social or economic development. Hence, building partnerships with government, parks and nature-oriented sites, educational institutions (schools, college) and other NGOs has been suggested as an appropriate solution to sustain and enhance the quality of EE/ESD (IGES, 2004; Yeshodhara, 2005)

\subsection{Overview of NGOs in Vietnam}

The first NGOs in Vietnam were international NGOs (INGOs) mainly working for humanitarian and emergency relief. Domestic NGOs first emerged in the early 1990s with enactment of a legal framework for operation of INGOs by the central government. Subsequently, the People's Aid Coordinating Committee (PACCOM) was established in 1996 under the Vietnam Union of Friendship Organizations (VUFO) to mobilize, coordinate and administer humanitarian and development activities of NGOs in Vietnam (Bach, 2003; Dang, 2009). Since that time NGOs have exerted a profound and growing influence in Vietnam. According to PACCOM's 10 year-report (2003-2013), approximately 990 INGOs were active as of 2013, conducting 28,000 projects throughout every province of Vietnam with total funding of about $\$ 2.4$ billion (PACCOM, 2013a).

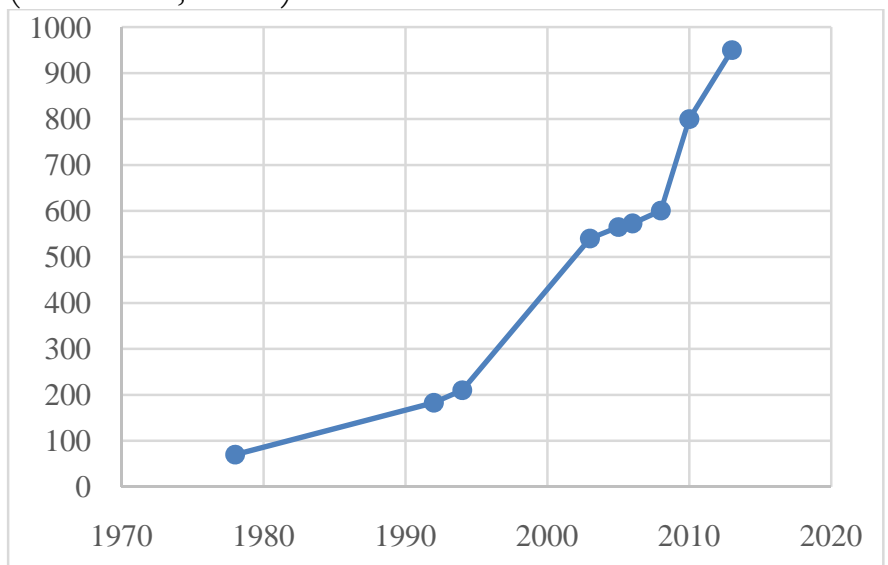

Figure 1. Number of international NGOs in Vietnam between 1978 and 2013 (PACCOM, 2013a, 2013b)

There has been a concomitant increase in the number of non-profit Vietnamese NGOs that have articulated clear social objectives (Singer, Pham, \& Hoang, 2014, p.96). All domestic NGOs and other civil society organizations must register with the Vietnam Union of Science and Technological Association (VUSTA) (Singer et al., 2014). Activities 
of domestic NGOs are similar to those of INGOs, with most related to community development, environment and sustainability, education and health. Leaders of the most prominent organizations are frequently former government officials or former INGO officials with strong networking skills who can procure funding and assistance from diverse sponsors (Singer et al., 2014).

Despite their rapid growth, there has been no clear legal definition of domestic NGOs and governing regulations have changed frequently. It is difficult to estimate an accurate number for domestic NGOs in VN since many organizations with limited scope and credibility register as or proclaim themselves to be NGOs for fundraising purposes. Many NGOs are small, with limited funding, operated by young and inexperienced staff with a high turnover (Singer et al., 2014).

Many NGOs suffer from a contentious relationship with the government. They are often regarded as unreliable, attention-seeking groups. On their part, due to the lack of a clear legal framework many NGOs are reluctant to initiate contact with authorities, especially at the local level, where governmental officials may be poorly informed about NGOs. Local authorities often consider NGOs and other civil society organizations as entities that need to be controlled rather than encouraged (Taylor, Nguyen, Pham, \& Huynh, 2012).

Vietnam has recently achieved middle-income economic status in terms of per capita GDP, a laudable milestone yet one that implies future heightened competition among local NGOs to secure diminishing pools of foreign official development assistance funding. In this context, boosting collaboration with universities, which are considered prestigious organizations, could enhance NGO opportunities for securing funds and grants and boost their professionalism in the future.

In light of recent recognition that Vietnam is one of the world's most vulnerable countries to climate change impacts and disaster risks, NGOs are paying increasing attention to promotion of sustainable development. The Vietnam Non-Governmental Organizations and Climate Change Network (VNGO\&CC) was formed in 2010 to foster and share knowledge and experience in climate change responses in general and sustainable development in particular by building youth capacity and leadership. By providing training courses and involving youth in environmental campaigns, NGOs have been effective in implementing environmental education and ESD across Vietnam.

A study of ESD implementation at the five most prominent TEIs in Vietnam revealed that NGOs could play a crucial role in training student teachers about ESD via nonformal education (Kieu, Singer, \& Gannon, 2016). The case study presented here seeks to deepen understanding of these partnerships to advance educational and research collaboration of universities and NGOs.

\section{Methodologies}

\subsection{Data collection}

This research was conducted at Danang University of Education (DUEd), a leading public teacher education institution in Vietnam. The university provides 12 undergraduate education programs. The authors had the opportunity to participate in several training activities organized by NGOs that allowed them to select five training programs for the study. Based on participant observation the authors designed questions 
and selected student participants in NGO courses for a focus group discussion (FGD) and NGO interviewees. Qualitative methods were applied to collect the data in this research as described in Table 1.

Table 1. Process of data collecting and analysis

\begin{tabular}{|l|l|l|l|}
\hline Targeted group & Methods & $\begin{array}{l}\text { Number of } \\
\text { participants }\end{array}$ & Purpose/Description \\
\hline $\begin{array}{l}\text { Student } \\
\text { teachers }\end{array}$ & FGD & $\begin{array}{l}\text { - Impressions of NGO-led ESD- } \\
\text { related training courses (trainees, } \\
\text { contents methods, } \\
\text { evaluation and motivation, personal } \\
\text { impact) - Compare NGO } \\
\text { sustainability-linked courses with } \\
\text { formal courses at DUEd }\end{array}$ \\
\hline NGO staff & $\begin{array}{l}\text { Semi-structured } \\
\text { interviews }\end{array}$ & 8 & $\begin{array}{l}\text { To understand how NGOs } \\
\text { organized ESD-linked training } \\
\text { courses and challenges }\end{array}$ \\
\hline DUEd lecturers & $\begin{array}{l}\text { Semi-structured } \\
\text { interviews }\end{array}$ & $\begin{array}{l}\text { Discussion of the contribution of } \\
\text { NGOs in promoting ESD at TEIs } \\
\text { and suggestions for strengthening } \\
\text { university - NGO partnership } \\
\text { (UNGOP) }\end{array}$ \\
\hline $\begin{array}{l}\text { NGO- } \\
\text { University staff }\end{array}$ & Focus group discussion & $\begin{array}{l}\text { NGO staff } \\
(5) \text { DUEd } \\
\text { staff (5) }\end{array}$ & $\begin{array}{l}\text { Identify prospective roles of NGOs } \\
\text { in training student teachers on ESD } \\
\text { and how to strengthen UNGOP }\end{array}$ \\
\hline
\end{tabular}

\subsection{Data analysis}

The authors analyzed data from the student focus group discussion to understand the contribution of NGOs in training teacher students about ESD, with semi-structured interviews supplying supplementary information. A framework of Wiek et al., (2016) was utilized to evaluate the influences of NGO courses on student teachers' sustainability competencies. This framework suggests six key competencies in sustainability that students should obtain:

- $\quad$ systems thinking competence

- futures thinking (or anticipatory) competence

- values thinking (or normative) competence

- $\quad$ Strategic thinking (or action-oriented) competence

- Collaboration (or interpersonal) competence and

- Integrated problem-solving competence

For each competency, Wiek et al. posited three levels of ability, including novice, intermediate and advanced.

\section{Results}

\subsection{NGOs' approaches in training teacher on ESD}

The burgeoning role of NGOs in empowering Vietnamese youth was underlined by the multifaceted involvement of student teachers at DUEd in activities organized by 
different NGOs. From interviews and focus group discussions, the authors identified seven NGOs conducting sustainability-linked awareness-raising at DUEd. This paper examines five NGO-led courses with differing approaches to explore the ways in which NGOs can contribute to training teachers in ESD. An overview of the five training courses, including ESD themes, pedagogies and motivation, is presented in Table 2.

Table 2. Overview of NGOs' contribution in training teacher students on ESD

\begin{tabular}{|c|c|c|c|c|c|}
\hline Name & $\begin{array}{l}\text { ESD-related } \\
\text { activities/themes }\end{array}$ & $\begin{array}{l}\text { Targeted } \\
\text { group }\end{array}$ & $\begin{array}{l}\text { Pedagogies } \\
\text { applied }\end{array}$ & Evaluation & $\begin{array}{l}\text { Follow-up } \\
\text { activities }\end{array}$ \\
\hline $\begin{array}{l}\text { Frankfurt } \\
\text { Zoology } \\
\text { Society } \\
\text { (FZS) }\end{array}$ & $\begin{array}{lr}\text { 10-daycourse } & \text { on } \\
\text { primate } & \text { and } \\
\text { biodiversity } & \\
\text { conservation } & \end{array}$ & $\begin{array}{l}\text { DUEd } \\
\text { students } \\
(18 \quad-\quad 20 \\
\text { participants })\end{array}$ & $\begin{array}{l}\text { Lectures by } \\
\text { FZS } \\
\text { staff/experts } \\
\text { in } \\
\text { biodiversity; } \\
\text { group } \\
\text { discussions: } 5 \\
\text { day- } \\
\text { experiential } \\
\text { learning in } \\
\text { forest }\end{array}$ & $\begin{array}{l}\text { Participation } \\
\text { and reports }\end{array}$ & $\begin{array}{l}\text { Funding } 5 \\
\text { proposals for } \\
\text { research or } \\
\text { raising public } \\
\text { awareness }\end{array}$ \\
\hline $\begin{array}{l}\text { SEEDs } \\
\text { Asia (SA) }\end{array}$ & $\begin{array}{lr}\text { 2-day course } & \text { on } \\
\text { education } & \text { for } \\
\text { disaster } & \text { risk } \\
\text { reduction } & \end{array}$ & $\begin{array}{l}42 \text { student } \\
\text { teachers } \\
\text { and } 4 \text { young } \\
\text { lecturers of } \\
\text { DUEd }\end{array}$ & $\begin{array}{l}\text { Lectures by } \\
\text { SA staff and } \\
\text { school } \\
\text { teachers, } \\
\text { group } \\
\text { discussions, } \\
\text { experiential } \\
\text { learning } \\
\text { (hazard } \\
\text { mapping and } \\
\text { teaching } \\
\text { material) }\end{array}$ & $\begin{array}{l}\text { Participation } \\
\text { and } \\
\text { presentations }\end{array}$ & None \\
\hline Live\&learn & $\begin{array}{l}\text { 4-week course to } \\
\text { build youth } \\
\text { leadership towards } \\
\text { sustainability }\end{array}$ & $\begin{array}{l}100 \\
\text { participants } \\
\text { aged } 18 \text { to } \\
25 \quad \text { from } \\
\text { across } \\
\text { Vietnam, } \\
\text { including } 6 \\
\text { DUEd } \\
\text { students }\end{array}$ & $\begin{array}{l}\text { Lectures by } \\
\text { noted } \\
\text { speakers, } \\
\text { group } \\
\text { discussions, } \\
\text { journal } \\
\text { entries, } \\
\text { project and } \\
\text { problem } \\
\text { based } \\
\text { learning }\end{array}$ & $\begin{array}{l}\text { Participation } \\
\text { and } \\
\text { proposals }\end{array}$ & $\begin{array}{l}\text { Funding of } \\
\text { best } \\
\text { proposals } \\
\text { from } \\
\text { participants, } \\
\text { creation of } \\
\text { website for } \\
\text { trainee } \\
\text { exchanges }\end{array}$ \\
\hline Greenviet & $\begin{array}{ll}\text { 2-day course } & \text { on } \\
\text { education } & \text { for } \\
\text { nature } & \\
\text { conservation } & \end{array}$ & $\begin{array}{l}50 \\
\text { volunteers } \\
\text { of } \\
\text { Greenviet } \\
\text { (11 DUEd } \\
\text { students) }\end{array}$ & $\begin{array}{l}\text { Lectures by } \\
\text { Greenviet } \\
\text { staff and } \\
\text { group } \\
\text { discussions }\end{array}$ & Participation & $\begin{array}{l}\text { Joining } \\
\text { program for } \\
\text { elementary, } \\
\text { secondary } \\
\text { students to } \\
\text { protect }\end{array}$ \\
\hline
\end{tabular}




\begin{tabular}{|c|c|c|c|c|c|}
\hline & & & & & $\begin{array}{l}\text { environment, } \\
\text { nature in Son } \\
\text { Tra peninsula }\end{array}$ \\
\hline $\begin{array}{l}\text { Action for } \\
\text { the city } \\
\text { (ACCD) }\end{array}$ & $\begin{array}{l}\text { 4-weekcourse on } \\
\text { sustainable } \\
\text { development }\end{array}$ & $\begin{array}{l}35 \\
\text { university } \\
\text { students (5 } \\
\text { from } \\
\text { DUEd) }\end{array}$ & $\begin{array}{l}\text { Lectures by } \\
\text { noted } \\
\text { speakers, } \\
\text { group } \\
\text { discussions, } \\
\text { project and } \\
\text { problem } \\
\text { based } \\
\text { learning }\end{array}$ & $\begin{array}{l}\text { Participation } \\
\text { and pilot } \\
\text { project } \\
\text { implementa- } \\
\text { tion }\end{array}$ & $\begin{array}{l}\text { Fund } \\
\text { students' } \\
\text { projects, } \\
\text { support } \\
\text { student clubs } \\
\text { to organize } \\
\text { sustainability } \\
\text { activities, } \\
\text { create } \\
\text { Facebook } \\
\text { page for } \\
\text { trainees }\end{array}$ \\
\hline
\end{tabular}

Although there was considerable variation in content, duration, evaluation and motivation, all of the courses featured interactive pedagogies. These included inviting school teachers to share with trainees practical experiences on integrating disaster risk reduction into curricula and creating teaching materials (SA), recruiting trainees from diverse disciplines and promoting mutual exchanges over a four-week course (ACCD), inviting noted sustainability experts and public figures to talk to trainees (ACCD and Live\&learn), fieldwork (organic farms, forest) (ACCD and FZS), and motivating trainees with such follow-up activities as projects, educational programs and public awarenessraising.

\subsection{Influence of NGO courses on student teachers' sustainability competencies}

The student focus group discussions revealed that students had predominantly positive impressions of the NGO-led training courses. Students claimed that they benefitted not only from the useful knowledge and sustainability practice purveyed by the courses but they had also improved personal skills such as group work, communication, financial management and self-orientation. Though such courses were not intentionally designed to improve trainees' teaching skills, three final-year students revealed that through their course they had been introduced to ESD pedagogical approaches. According to the student teachers, lectures featured practical knowledge rather than abstract theories, speakers provided interesting lectures with ample opportunities to ask questions, and group discussions were organized creatively by applying such techniques as student storytelling, brainstorming, think-pair share, roleplaying, problem-based learning, and experiential learning by participating in projects or visiting field sites. Course evaluation was mainly based on the students' active participation during the course, as judged by NGO officials and sometimes by other trainees. Noted one student:

The ACCD course provided me with innumerable impressive and new experiences. I met well-known figures who taught us about sustainable development and individual motivation (e.g. author Nguyen Ngoc, journalist Ta Bich Loan). This was my first time to meet and work with the farmers engaged in organic agriculture. It was the first time to stay with students from various regions of Vietnam in a homestay. We were awarded 4 
million VND to realize our proposal of an organic school garden at Nguyen Thi Luu junior high school. It was absolutely unforgettable (female student, $4^{\text {th }}$ year).

When asked about the influence of the courses on their knowledge of sustainability, several students lauded the follow-up activities after the courses as being most beneficial, in that it allowed them to apply what they had learned. Student focus group participants indicated that they have achieved three core sustainability competencies (of six proposed by the framework of Wiek et al. (2016)) by participating in NGO courses, specifically:

o Systems thinking: the students gained an understanding of the complexity and challenges facing sustainability and cause-effect chains. Comments included: "organic products are environmentally friendly but usually more expensive than other products so it is difficult to increase organic food consumption in impoverished areas"; "staying in the forest enabled me to have a comprehensive understanding of ecosystems, the role of each species and the abiding connections between nature and humans", and "serious beach erosion in Hoi An is the certain consequence of hydropower dams and the loss of forests of Nipa palm".

o Future thinking: Students expressed their concerns about many ongoing issues in Vietnam such as corruption, climate change, food safety, environmental pollution and socially alienated lifestyles for young people ("overuse of chemical compounds in Vietnam will lead to many diseases, of which cancer is the nightmare of many families", "I worry about the future of Vietnam because many young people are spending a lot of time on Facebook or games")

o Values thinking and action-orientation: Students understood the need to adopt more environmentally friendly behavior ("I perceived the alarming cumulative impacts of societal and environmental problems. We young people must reorient our lifestyles and inspire each other to save the earth"; "I feel more responsible because even small changes in my daily habits like using water or energy can help mitigate climate change") During the discussion, students explained about their own post-course behavioral changes, mainly changing their daily habits to reduce consumption of water and energy and planting vegetables in small planters. Some also mentioned that they were involved in environmental campaigns or charity work organized by either university or outside sectors but few of them were able to work with local communities as they had done during the NGO-led courses because of their busy academic schedule and remote locations.

Students increased their sustainability-related competencies but not their ESD teaching competencies, mainly because the courses were not specifically designed for student teachers. As future teachers, students need to obtain pedagogical competence and experience methods for engaging others to learn and act towards sustainability.

Students identified a few drawbacks of NGO courses such as overly ambitious course schedules, a lack of supervision during the follow-up activities, lengthy lectures and misleading trainee recruitment. Since the NGOs bore all costs for the training courses and widely recruited trainees, only a few outstanding DUEd students could participate. Additionally, because NGOs like Live\&learn didn't coordinate their class schedules with those of DUEd, some students had to miss university classes without the permission of faculty members to participate in courses. During discussions students explained that they had purveyed additional critical comments to the NGOs after each course. 


\subsection{Challenges of implementation of NGO training}

Despite clear achievements in training students on ESD, there remain various challenges that NGOs have to face. Interview of NGOs identified several problems common to their training courses. First is lack of interest of local government and assistance from VUSTA. Those two organizations play crucial roles to connect NGOs with universities to recruit trainees and local authorities. NGOs need to obtain official permission from local government for arranging students to stay and work with local communities. According to interviewees, due to a lack of such official permission, NGOs sometimes must arrange hotels for students' accommodation that are expensive and lack a sense of connection with local communities. Second is pressure from NGO donors or sponsors. Raising funds is the most significant but challenging task of NGOs. Their work largely depends on the donors' requirements which are very rigorous. Hence, NGOs must adapt such requirements in local contexts.

According to NGO staff interviewees, in student training programs it is necessary for NGO staff to devote extra time to train students basic "soft skills" because of students are unfamiliar with field work at the start. Interviewees claimed that students lack practical knowledge (e.g. basic knowledge of soil characteristics, organic material processes and seasonal flooding vulnerability season) and lacked discipline (e.g. being late at first, missing meetings without providing any notice).

Students did not even know how to use essential equipment in the forest such as binoculars and compasses. They did not know how to light a fire or how to cook in the forest. Moreover, at the start, two students were not able to erect their tent. We also needed to train them in group work skills and communication skills to collaborate with the staff of the National Park and with each other. (32, female)

Insufficient collaboration with DUEd resulted in some misunderstanding during the training course (i.e. overlapped schedules). NGO staff expressed their displeasure because of a lack of responsiveness from university members who did not prioritize collaboration with NGOs in such training courses.

\section{Discussion}

\subsection{Analyzing roles for NGOs in ESD at teacher education institutions}

NGOs in Vietnam are playing a growing role in ESD, but NGO partnership and approaches remain a novel concept for many university lecturers. It is difficult for oversubscribed university lecturers to harness the necessary funding, time, manpower and diverse field sites to organize courses like those offered by NGOs, and they may not be comfortable with the active learning approaches that are commonly applied. Given these drawbacks, NGOs can serve as crucial non-formal educators of sustainability. In fact, the results from the DUEd case study imply that NGOs have significantly contributed to fostering sustainability-linked competencies and inspiring student teachers to consider implementing active learning pedagogies in their future teaching. Although many of the courses were of limited duration, NGOs create good conditions that empower students towards behavioral change (i.e. creating a data bank of sustainability, funding students' proposals, etc.). At the end of the FGD, students made a comparison between NGO and DUEd sustainability-linked courses as presented in Table 3. 
Table 3. Comparison between NGO and DUEd sustainability-linked courses

\begin{tabular}{|c|c|c|}
\hline $\begin{array}{l}\text { Comparison } \\
\text { aspect }\end{array}$ & NGOs & DUEd \\
\hline $\begin{array}{l}\text { Teaching } \\
\text { duration }\end{array}$ & $\begin{array}{l}\text { Short and intensive (several days } \\
\text { to } 4 \text { weeks) }\end{array}$ & Several semesters \\
\hline $\begin{array}{l}\text { Teaching } \\
\text { contents }\end{array}$ & $\begin{array}{l}\text { - Short, updated and concise } \\
\text { with local \& practical knowledge } \\
\text { - Target at building skills }\end{array}$ & $\begin{array}{l}\text { - Important and basic concepts \& principles } \\
\text { but too heavy (mainly theory-based) } \\
\text { - Target at memorizing knowledge }\end{array}$ \\
\hline $\begin{array}{l}\text { Teaching } \\
\text { methods }\end{array}$ & $\begin{array}{l}\text { Very interactive (enquiry-based, } \\
\text { experiential learning) }\end{array}$ & $\begin{array}{l}\text { Lectures }(70 \%-80 \%) \text {, seminars \& group } \\
\text { discussion }(20 \%-30 \%)\end{array}$ \\
\hline Evaluation & $\begin{array}{l}\text { - Competency-based evaluation } \\
\text { via participation, proposal \& } \\
\text { final products (i.e. videos, } \\
\text { booklets) } \\
\text { - No accreditation }\end{array}$ & $\begin{array}{l}\text { Knowledge-based evaluation via writing test, } \\
\text { assignments \& presentation at mid-term and } \\
\text { end of semester }\end{array}$ \\
\hline Motivation & $\begin{array}{l}\text { - Allow trainees to become } \\
\text { volunteers } \\
\text { - Network trainees via } \\
\text { facebook/website/mail group } \\
\text { - Encouraged trainees to form } \\
\text { clubs to organize sustainability- } \\
\text { related activities } \\
\text { - Fund trainees' mini-projects } \\
\text { and/or introduce them to other } \\
\text { sponsors }\end{array}$ & Not clear \\
\hline $\begin{array}{l}\text { Number of } \\
\text { trainees }\end{array}$ & $\begin{array}{l}\text { - Very few (10 to 20), only } \\
\text { active \& outstanding students } \\
\text { - Different majors }\end{array}$ & $\begin{array}{l}\text { - All students } \\
\text { - Same major }\end{array}$ \\
\hline
\end{tabular}

When these results were shared with six of 12 interviewed lecturers who had experienced NGO training courses (as trainees and trainers) and all of them concurred with these assessments. Interviewed lecturers claimed that some teaching approaches of NGOs have been applied at DUEd, including updating the global context of sustainability, increasing skill-based teaching and collaborating with foreign educational institutions to promote knowledge exchanges, organizing a field trip (only one field trip for a four-year education program) and inviting governmental officials to talk about environmental issues. Yet they admitted that novel approaches can't yet meet student demand because of large-sized classes, the time and energy required, and the low willingness of lecturers. Hence, other initiatives of NGOs such as bringing students from diverse disciplines to work together, sending students to stay and work with farmers, and the motivation/follow-up activities are very unique and useful to build and improve students' sustainability competencies.

Indeed, NGOs can not only teach ESD courses, they can also motivate teacher education institutions to improve their ESD teaching capacity. First, as explained earlier NGOs can serve as a data bank (Turnock, 2004; Yeshodhara, 2005) that provides TEIs with sustainability-related knowledge and practices as well as ESD pedagogical source material on online websites like thehebenvung.com or vidothi.org. Although ESD has 
been embedded in teacher education curricula to some extent, lecturers continue to mainly focus on equipping students with knowledge of sustainability (Kieu et al., 2016). Hence, by participating in NGO training activities, university lecturers and teacher students may gain valuable opportunities for learning experiential education strategies to apply in teaching about environment and sustainability. Secondly, most NGO course participants are outstanding students and frequently leaders of clubs or student association, thus they are able to promote extra-curricular activities on campus. Thirdly, once a university regards NGOs as prospective employers, they may encourage faculty to revise curricula to increase ESD content. Additionally, focus group of NGO and DUEd staff implies that NGOs may be fund raisers and supporters for sustainability activities/projects at TEIs.

Finally, NGOs can play an important role in promoting university outreach. In all five training courses, NGOs connected university students to local communities, including sustainability-minded farmers at organic farms (ACCD), school teachers and students in Danang and Hoi An (SA, Greenviet and ACCD), Kon Ka Kinh National Park officials (FZS), famous speakers (Live\&learn and ACCD) and youths from across Vietnam. Thanks to NGO connections and funding, students could apply their knowledge to construct organic gardens, organize campaigns to raise public awareness of biodiversity and nature conservation and carry out environmental education at elementary and junior high schools, all of which are closely related to their future careers. Given the wealth of knowledge at NGOs, it would obviously be of benefit if universities promoted NGOs as hosts for student internships (Roche, 2013).

Based on the analysis of interview results, literature review of NGO complementary spheres of education (Blum, 2009; Haigh, 2006; Mendenhall \& Anderson, 2013; P. Adinarayana Reddy \& Reddy, 2006) and NGO - DUEd focus group, the authors would also suggest that NGOs become involved in formal university education as well as their current informal and non-formal activities. A framework for NGO involvement in training teachers is presented in Figure 1.

\section{Formal education}

NGO staff can serve as:

- Advisors for ESD courses

- Visiting lecturers

- Thesis supervisors

- Research advisors and supporters

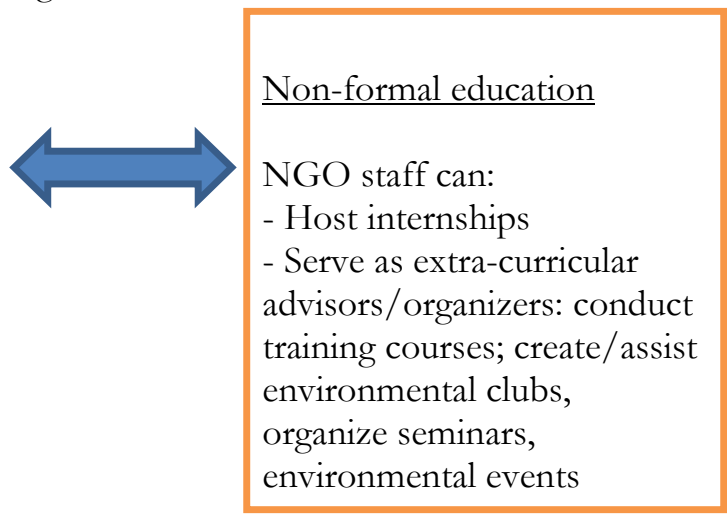

Figure 2. Involvement of NGOs for training teachers in ESD 


\subsection{Promoting UNGOP - A key solution for ESD advancement at TEIs}

The suggested prospective roles of NGOs accompany continuing collaboration with universities. Yet despite the fact that DUEd has maintained relationships with NGOs since early 2000s, the overall level of their collaboration has remained poor. The partnership typically ceases as the project comes to an end. This short-term collaboration may result in a lack of interest from the university. On the other hand, NGOs are often wary of universities' slow and complicated bureaucracy, and they fear that the university will interfere with their activities (M. C. R. Reddy \& Ramakrishna, 2006). The independent existence of both NGOs and university is also a factor leading to a lack of perceived mutual interests.

Improving UNGOPs requires sustained efforts. Ten conditions suggested by Reghu (2006) for facilitating UNGOPs include mutual understanding, respect and acceptance; a positive attitude by university administrators and NGO staff; faith in the program; willingness to learn and act; fruitful time management; proper support and encouragement from the concerned; mutual learning; team work to achieve the goal; a sense of social commitment; and a tolerant atmosphere. The partnerships cost both sides a great deal of time and manpower but can yield great benefit. Active participation of lecturers is a key factor in creating reliability and increasing NGO interest in collaboration. Based on the suggestions of many of the interviewees three initial steps have been suggested to enhance UNGOPs:

1. The university should contact and collaborate with the city or provincial department of foreign affairs (managing INGOs at local level) and VUSTA (managing domestic NGOs) to stimulate dialogues between NGOs and university (via workshops, meetings or group discussions). Regular communications will allow to establish generate clear, specific, and realistic purposes that are core elements of the successful partnership (Baum, 2000).

2. The university must select suitable and reliable NGO partners. Some criteria for selection, according to Reddy (2006), include: Substantial experience in sustainabilitylinked fields, adequate financial capacity, sound management and qualified staff, and long-term commitment to collaboration.

3. The university needs to facilitate NGO activities by providing facilities and venues for NGO programs, minimizing red tape, and organizing a group of sustainability-related teaching lecturers to assist NGOs, co-write grant proposals and exchange knowledge and experience in seminars and workshops.

\section{Conclusion}

NGOs are pioneers in engaging Vietnamese youth in sustainability through diverse themes (i.e. environmental education, climate change education) under the umbrella of ESD. A case study of DUEd examined several NGO-led training courses addressing sustainability themes and employing various interactive pedagogies. The courses were found to have positively enhanced student teachers' understanding of sustainable development. Students enhanced key competencies in sustainability such as systems thinking, future thinking and values thinking which potentially result in environmentally friendly behaviors. They also came to understand the significance of 
active pedagogies in teaching ESD. Students in a focus group saw NGOs as crucial educators in non-formal ESD and as contributing to promoting ESD at TEIs by helping to raise funds and to provide research funding, offering the promise of future employment and reviewing curriculum.

The potential contribution of NGOs that emerged from the above analysis suggests that university should be more active in strengthening partnership with NGOs. In order to strengthen the partnership, there needs to be sustained, government-facilitated dialogue, selection of suitable NGO partners and more active participation by university members.

\section{References}

Bach, T. S. (2003). Civil Society and NGOs in Vietnam: Some Initial Thoughts on Developments and Obstacles. Paper presented at the Meeting with the Delegation of the Swedish Parliamentary Commission on Swedish Policy for Global Development to Vietnam. Retrieved from http://www.ngocentre.org.vn/files/docs/CSandNGOs in Vietnam.rtf

Baum, H. S. (2000). Fantasies and Realities in University-Community Partnerships. Journal of Planning Education and Research, 20(2), 234-246.

Blum, N. (2009). Teaching science or cultivating values? Conservation NGOs and environmental education in Costa Rica. Environmental Education Research, 15(6), 715-729.

Dang, L. H. (2009). Non-Governmental Organizations (NGOs) and Development: An Illustration of NGOs in Vietnam. $\mathrm{PhD}$ thesis. Ohio University. Retrieved from https://etd.ohiolink.edu/rws_etd/document/get/ohiou1243905289/inline

egnbol-Martinussen, J., \& Engberg-Pedersen, P. (2003). Aid: understanding international development cooperation. London: Zed Books.

Haigh, M. J. (2006). Promoting Environmental Education for Sustainable Development: The Value of Links between Higher Education and Non-Governmental Organizations (NGOs). Journal of Geography in Higher Education, 30(2), 327-349. http://doi.org/10.1080/03098260600717422

Hopkins, C. (2014). Scope and Impact of Global Actions under UNDESD. Journal of Education for Sustainable Development, 8(2), 113-119.

IGES. (2004). Asia-Pacific Environmental Innovation Strategies (APEIS) Research on Innovative and Strategic Policy Options (RISPO) Good Practices Inventory. Second Progress Report. Retrieved from http://enviroscope.iges.or.jp/contents/APEIS/RISPO/p_report_2nd/11_3_3_2_promoting_en vironmental_education_by_ngos.pdf

Jia-nan, C. (2012). Contributions of Environmental NGO to Environmental Education in China. IERI Procedia, 2, 901-906. http://doi.org/10.1016/j.ieri.2012.06.189

Kieu, T. K., Singer, J., \& Gannon, T. (2016). Education for Sustainable Development in Vietnam: Lessons learned from teacher training. International Journal of Sustainability in Higher Education, 17(6), scheduled to be published.

Mendenhall, M., \& Anderson, A. (2013). Bridging the gaps. Harvard International Review, 35(1), 62-66.

Mochizuki, Y. (2016). Introduction. Top-down and bottom-up ESD: divergence and convergence of Japanese ESD discourses and practices. In Singer, J., Gannon, TJ., Noguchi, F., and Mochizuki, Y., eds., Educating for sustainability in Japan: fostering resilient communities after the triple disaster. Oxford: Routledge Publishers.

PACCOM. (2013a). Collaboration between Vietnam and iNGOs for the period 2003-2013. Retrieved December 3, 2015, from http://vietnamnet.vn/vn/chinh-tri/151491/990-to-chuc-phi-chinh-phuquoc-te-hoat-dong-tai-vn.html

PACCOM. (2013b). The 3rd international conference on collaboration between Vietnam and foreign NGOs. Retrieved December 19, 2015, from http://comingo.gov.vn/chitiet/thong-tin-hoatdong/hoi-nghi-quoc-te-lan-3-ve-hop-tac-giua-viet-nam-va-cac-to-chuc-phi-chinh-phu-nuocngoai.aspx

Prins, E. (2005). Framing a Conflict in a Community-University Partnership. Journal of Planning Education and Research, 25(1), 57-74. 
Reddy, M. C. R., \& Ramakrishna, D. (2006). Problems and Prospects of University-NGO Partnership NGOs Point of View. In P. A. Reddy \& M. C. R. Reddy (Eds.), Universities and NGOs (first, pp. 10-16). New Delhi: Discovery Publishing House.

Reddy, P. A., \& Reddy, M. C. R. (2006). Universities and NGOs (first). New Delhi: Discovery Publishing House.

Reghu, V. (2006). University-NGO linkage: A New Dimenssion to Extension Programmes. In M. C. R. Reddy \& P. A. Reddy (Eds.), Universities and NGOs (first, pp. 46-52). New Delhi: Discovery Publishing House.

Roche, C. (2013). Effective partnerships between NGOs, civil society organisations \& universities. Retrieved September 17, 2015, from https://beyond2015.acu.ac.uk/submissions/view?id=47

Singer, J., Pham, H. T., \& Hoang, H. (2014). Broadening stakeholder participation to improve outcomes for dam-forced resettlement in Vietnam. Water Resources and Rural Development, 4, 94-98.

Taylor, W., Nguyen, T. H., Pham, Q. T., \& Huynh, T. N. T. (2012). Civil Society in Vietnam: A comparative study of civil society organizations in Hanoi and Ho Chi Minh City. Hanoi.

Turnock, D. (2004). The Role of NGOs in Environmental Education in South-eastern Europe The Role of NGOs in Environmental Education in South-eastern Europe. International Research in Geographical and Environmental Education, 13(1), 37-41. http://doi.org/10.1080/10382040408668800

Ulleberg, I. (2009). The role and impact of NGOs in capacity development: From replacing the state to reinvigorating education. International Institute for Educational Planning. Retrieved from http://unesdoc.unesco.org/images/0018/001869/186980e.pdf

Wiek, A., Bernstein, M. J., Foley, R. W., Cohen, M., Forrest, N., Kuzdas, C., ... Withycombe Keeler, L. (2016). Operationalising competencies in higher education for sustainable development. Routledge Handbook of Higher Education for Sustainable Development.

Yeshodhara, K. (2005). Role of NGOs in promoting Non-formal environmental education: a case study. Social and economic change monographs series (Vol. 10). 